\title{
Dead Cover and Agronomic Characteristics of Cowpea
}

\author{
Vilson de Souza Rocha ${ }^{1}$, Ajax de Sousa Ferreira ${ }^{1}$, Bruna Nogueira Leite ${ }^{1}$, Carla Coelho Ferreira ${ }^{1}$, \\ Karla Gabrielle Dutra Pinto ${ }^{1}$, Sara Cruz Pinheiro ${ }^{2} \&$ Sônia Maria Figueiredo Albertino ${ }^{1}$ \\ ${ }^{1}$ Postgraduate Program in Tropical Agronomy, Federal University of Amazonas, Manaus, Brazil \\ ${ }^{2}$ Faculty of Agricultural Sciences, Federal University of Amazonas, Manaus, Brazil \\ Correspondence: Sônia Maria Figueiredo Albertino, Postgraduate Program in Tropical Agronomy, Federal \\ University of Amazonas, Manaus, Brazil. Tel: 55-92-9988-5607. E-mail: sonia.albertino@gmail.com
}

Received: February 27, 2020

Accepted: August 19, $2020 \quad$ Online Published: September 15, 2020

doi:10.5539/jas.v12n10p175

URL: https://doi.org/10.5539/jas.v12n10p175

\begin{abstract}
Dead cover, or mulch, consisting of plant residues, plays an important role for the success of diverse agricultural crops, working as an insulating layer protecting the soil from daytime temperature variations and maintaining the soil moist and rich in organic matter. Cowpea is a source of proteins, carbohydrates, vitamins and minerals. Its importance in the North, Northeast and Midwest regions of the country is associated with economic and social aspects, since it is an important food for low-income populations, supplying their nutritional needs. This study was carried out under greenhouse conditions in Manaus, state of Amazonas, with the purpose of assessing the effect of different dead covers on the agronomic characteristics of cowpea cultivars. It consisted of a completely randomized design in a $4 \times 4$ factorial arrangement. The treatments comprised four cowpea cultivars (BRS Caldeirão, BRS Tumucumaque, BRS Guariba and BRS Tracuateua) and three species of cover plants (Brachiaria decumbens, Brachiaria ruziziensis and Mucuna pruriens) and one control treatment, without soil cover, in a total of 16 treatments, with four replications and two plants per experimental unit. Analysis of variance was applied to the data, and the means were compared by the Scott-Knott's test at $5 \%$ probability level. The following characteristics were examined: number of pods per plant, pod length, number of seeds per pod, weight of shoot dry matter, and grain yield. Mulching provided better results for all characteristics assessed in the four cultivars when compared to the control. BRS Caldeirão is the recommended cultivar for the state of Amazonas and the other regions with similar edaphoclimatic characteristics (high air temperature, rainfall, air humidity, and low-fertility tropical soils) because it exhibited the greatest number of pods per plant, number of seeds per pod, shoot dry matter, and the highest average grain yield (Freire Filho et al., 2011; Souza et al., 2016).
\end{abstract}

Keywords: mulch, plant cover, productivity, Vigna unguiculata

\section{Introduction}

Cowpea (Vigna unguiculata) is a legume that integrates the staple diets of populations in developing countries, rich in proteins, minerals, and fibers (Frota et al., 2008). In addition to providing an important food supply, it generates jobs and income to farmers (Freire Filho et al., 2011).

In Brazil, cowpea is largely cultivated in the North and Northeast regions of Brazil by small farmers (Locatelli et al., 2014), but the production of this legume has grown in the Midwest in recent years due to its high adaptability to tropical conditions, low production costs, and the intense genetic improvement efforts that have been applied to the culture (Freire Filho et al., 2011).

Although it is considered a rustic crop, cowpea responds well to improvements in cultivation methods, and for this reason cropping practices designed to raise productivity and promote sustainable development must be tested. Among these technologies, dead soil cover has been used to maintain and/or improve soil fertility, prevent erosion, reduce heat and water loss, and also to suppress weed species (Favarato, de Souza, \& Guarçoni, 2017).

When deciding for the use of mulch, various factors must be taken into consideration, such as its capacity to retain water, increase soil porosity, enhance beneficial macrobiotics, in addition to being a source of nutrients for the crop (Souza et al., 2016).

The availability of nutrients contained in plant residues varies according to the species used as mulch. Legumes have the advantage of having a great potential of biomass production and the ability to form a symbiotic 
association with the nitrogen-fixing bacteria, enriching this nutrient in the tissues and providing it to the crop (Costa et al., 2015).

Grass plants are an alternative because they have a high $\mathrm{C} / \mathrm{N}$ ratio and, therefore, a low decomposition rate, protect the soil for longer periods, conserve soil moisture and nutrients cycling, with less variation in the soil temperature (Torres, Cunha, Pereira, \& Vieira, 2014). Given the above, this work aimed to evaluate the effect of different mulches on agronomic characteristics of cowpea cultivars.

\section{Method}

The experiment was carried out in the experimental area of the Federal University of Amazonas (UFAM), Manaus, Brazil $\left(3^{\circ} 06^{\prime} 03.2^{\prime \prime} \mathrm{S}\right.$ and $\left.59^{\circ} 58^{\prime} 38.3^{\prime \prime} \mathrm{W}\right)$. The average annual temperature, rainfall and humidity were, respectively, 25 to $28^{\circ} \mathrm{C}, 2,100 \mathrm{~mm}$ and 84 to $90 \%$ (Ribeiro et al., 1999).

The experimental design consisted of completely randomized design with $4 \times 4$ factorial arrangement, using four cowpea cultivars (BRS-Caldeirão, BRS-Tumucumaque, BRS-Guariba and BRS-Tracuateua) cultivated on three mulch layers (Brachiaria decumbens, Brachiaria ruziziensis and Mucuna pruriens), and a control treatment (without mulch), with four replications, totaling 64 experimental units.

Each experimental unit consisted of a polyethylene pot measuring $23 \mathrm{~cm}$ in diameter and $17 \mathrm{~cm}$ in height, filled with $5.104 \mathrm{dm}^{3}$ of substrate. Each pot contained two cowpea plants, spaced $10 \mathrm{~cm}$ apart inside each pot, and 50 $\mathrm{cm}$ distant from each pot.

The soil used as substrate was classified as Yellow Latosol, collected at the Production Sector of the Faculty of Agrarian Sciences, UFAM. This substrate had a pH value of 3.9; $6 \mathrm{mg} \mathrm{dm}^{-3}$ of phosphorus; $18 \mathrm{mg} \mathrm{dm}^{-3}$ of potassium; $0.3 \mathrm{cmolc} \mathrm{dm}^{-3}$ of calcium; $0.25 \mathrm{cmolc} \mathrm{dm}$ of magnesium; $7.2 \mathrm{cmolc} \mathrm{dm}^{-3}$ of potential acidity $\left(\mathrm{H}^{+}+\right.$ $\left.\mathrm{Al}^{3+}\right) ; 1.3 \mathrm{cmolc} \mathrm{dm}^{-3}$ of aluminum $\left(\mathrm{Al}^{3+}\right)$; and $4.1 \mathrm{~g} \mathrm{~kg}^{-1}$ of organic matter.

Correction of soil acidity and fertilization were carried out based on the soil analysis and recommendations for the culture. Dolomitic limestone was used for liming (90\% Relative Total Neutralization Power). After 90 days allowed for the liming reaction, cover fertilization was performed at the rate of $70 \mathrm{~kg} \mathrm{ha}^{-1}$ of $\mathrm{P}_{2} \mathrm{O}_{5}$ and $60 \mathrm{~kg} \mathrm{ha}^{-1}$ of $\mathrm{K}_{2} \mathrm{O}$, of simple superphosphate and potassium chloride sources, respectively (Novais \& Alvarez, 2002; Sousa, de Castro, Damasceno, \& de Matos, 2019).

Sowing was conducted ten days after fertilization, at a depth of $2.0 \mathrm{~cm}$ from the surface, with four seeds per pot. After 15 days, thinning was done, and the two most vigorous plants, with good phytosanitary aspects, were maintained. After thinning the seedlings, a 4-cm thick layer of each plant cover species, according to the treatments described above, was spread on the soil surface. The plant material used as mulch in the experiment was specifically cultivated for this purpose in an area of $30-\mathrm{m}^{2}$. The plants were dried during 20 days in natural environment. Using scissors, the material was cut into pieces to be accommodated in the pots.

After harvest, the mean values of each experimental unit were analyzed to determine the following agronomic characteristics: a) Number of pods per plant (NPP) - total number of pods with at least one seed, divided by the number of plants; b) Pod length (PL) - measured with metric tape; c) Number of seeds per pod (NSP) - ratio of the total number of seeds to the total number of pods; d) Shoot dry matter (SDM) - obtained by drying leaves, stems and petiole in a forced-air circulation oven at $65^{\circ} \mathrm{C}$ to constant weight; weighing on an analytical scale; e) Grain yield (GY) - grain weighing (13\% of moisture), and transformation of data to $\mathrm{kg} \mathrm{ha}^{-1}$ (Camara, Mota, Nicolau, Pinto, \& Silva, 2018).

The data were subjected to analysis of variance, and the means were compared by the Scott-Knott test $(\mathrm{p}<0.05)$. The software Assistat, version 7.7, was used (Silva \& Azevedo, 2016).

\section{Results}

Flowering started at 32, 35, 36 and 38 days after sowing, and pods of BRS Tracuateua, BRS Guariba, BRS Caldeirão and BRS Tumucumaque were harvested at 61, 61, 62 and 66 days, respectively. They were classified as early-cycle cultivars. Pests and diseases were not found during the experiment nor weeds occurrence.

The cultivars exhibited better results with mulching compared to the control, but the cover species used did not differ from each other. The cultivar $\times$ dead cover interaction was not significant. However, for all parameters assessed, there were significant differences for the cultivars, which confirms the great genetic variability of the species. Likewise, the mulch factor also influenced all variables analyzed (Tables 1 and 2).

Ranking of cultivars according to the number of pods per plant was: BRS Caldeirão $>$ BRS Tumucumaque $=$ BRS Guariba > BRS Tracuateua. For the pod length, it was: BRS Tumucumaque > BRS Guariba $>$ BRS Caldeirão $=$ BRS Tracuateua. For the number of seeds per pod: BRS Guariba $=$ BRS Caldeirão $>$ BRS 
Tumucumaque $=$ Tracuateua (Table 1$)$. For shoot dry matter, cultivars BRS Caldeirão, BRS Tumucumaque and BRS Guariba exhibited the highest averages, not differing from one another. But BRS Tracuateua was the cultivar with the lowest production of dry matter. Ranking for average grain yield was: BRS Caldeirão $=$ BRS Guariba $>$ BRS Tumucumaque $=$ BRS Tracuateua (Table 2).

Table 1. Mean values for the number of pods per plant (NPP), pod length (PL), number of seeds per pod (NSP), of four cowpea species cultivated with different soil cover

\begin{tabular}{llll}
\hline & NPP & PL $(\mathrm{cm})$ & NSP \\
\hline Average of cultivars & & & \\
BRS Caldeirão & $13.25 \mathrm{a}$ & $13.37 \mathrm{c}$ & $9.85 \mathrm{a}$ \\
BRS Tumucumaque & $9.50 \mathrm{~b}$ & $18.63 \mathrm{a}$ & $8.99 \mathrm{~b}$ \\
BRS Guariba & $9.40 \mathrm{~b}$ & $17.30 \mathrm{~b}$ & $10.31 \mathrm{a}$ \\
BRS Tracuateua & $6.75 \mathrm{c}$ & $13.99 \mathrm{c}$ & $8.59 \mathrm{~b}$ \\
\hline Average soil mulches & & & \\
B. ruziziensis & $10.12 \mathrm{a}$ & $16.51 \mathrm{a}$ & $9.71 \mathrm{a}$ \\
B. decumbens & $10.56 \mathrm{a}$ & $15.96 \mathrm{a}$ & $9.59 \mathrm{a}$ \\
M. pruriens & $10.22 \mathrm{a}$ & $16.48 \mathrm{a}$ & $10.09 \mathrm{a}$ \\
Control & $8.00 \mathrm{~b}$ & $14.35 \mathrm{~b}$ & $8.35 \mathrm{~b}$ \\
\hline
\end{tabular}

Note. Means followed by the same letters in the column do not differ by the Scott-Knott test $(\mathrm{p}<0.05)$.

Table 2. Mean values for accumulated shoot dry matter (SDM) and grain yield (GY) of four cowpea species cultivated with different soil cover

\begin{tabular}{lll}
\hline & SDM $(\mathrm{g})$ & $\mathrm{GY}\left(\mathrm{kg} \mathrm{ha}^{-1}\right)$ \\
\hline Average of cultivars & \\
BRS Caldeirão & $24.08 \mathrm{a}$ & $977.32 \mathrm{a}$ \\
BRS Tumucumaque & $21.87 \mathrm{a}$ & $758.83 \mathrm{~b}$ \\
BRS Guariba & $22.24 \mathrm{a}$ & $952.73 \mathrm{a}$ \\
BRS Tracuateua & $15.14 \mathrm{~b}$ & $595.24 \mathrm{~b}$ \\
Average soil mulches & & \\
B. ruziziensis & $22.46 \mathrm{a}$ & $853.79 \mathrm{a}$ \\
B. decumbens & $21.27 \mathrm{a}$ & $856.47 \mathrm{a}$ \\
M. pruriens & $22.56 \mathrm{a}$ & $902.41 \mathrm{a}$ \\
Control & $17.05 \mathrm{~b}$ & $671.45 \mathrm{~b}$ \\
\hline
\end{tabular}

Note. Means followed by the same letters in the column do not differ by the Scott-Knott test $(\mathrm{p}<0.05)$.

\section{Discussion}

All cowpea species studied were classified as early-cycle cultivars, which is an advantageous aspect for producers because it allows faster financial returns due to the shorter time in field, in addition to the shorter time of exposure to possible adverse weather, reducing risks of crop losses (Freire Filho et al.,2011; Osipitan, 2017).

The absence of attacks by pests or diseases may be related to the mulch ability to prevent soil pathogens from spreading on the plant' shoots by water splashed during the irrigation process (Pereira \& Pinheiro, 2012).

There was no occurrence of weeds during the cowpea productive cycle. Mulch has the ability to gradually hinder increase of the weed seed bank by preventing the incidence of sunlight required for germination, or functioning as a physical barrier to the emergence of seedlings, minimizing their regrowth, thus reducing control costs and representing a viable alternative (Maia Júnior et al., 2019).

Of all cultivars studied, the cv. BRS Caldeirão indicated the best agronomic performance. It exhibited the greatest number of pods per plant, number of seeds per pod, shoot dry matter, and the highest average grain yield. It was followed by cv. BRS Guariba, which was not different from cv. BRS Caldeirão in number of seeds per pod, average grain yield and shoot dry matter, and exhibited the second greater number of pods per plant and the second longer pod length (Tables 1 and 2). 
The number of pods per plant is a production component that is directly related to productivity, being an effective parameter to define the cowpea cultivar to be chosen by farmers (Silva \& Neves, 2011; Bezerra, Neves, Alcântara Neto, \& Silva Júnior, 2014). Similar results were obtained by Locatelli et al. (2014) when they studied the productivity of cultivars BRS Guariba, BRS Nova Era and BRS Pajeú cultivated in no-tillage system with mulch cover (straw) of Brachiaria ruziziensis, where the NPP was 9.5, 12.84 and 11.08, respectively.

With respect to pod length (Table 1), all cultivars exhibited lower values than those found by Silva and Neves (2011), who recorded average lengths of $19.7 \mathrm{~cm}$ and $20 \mathrm{~cm}$ in rainfed and irrigated cultivation, respectively. But they were higher than the ones found by Bertini, Teófilo, and Dias (2009), who recorded $11.9 \mathrm{~cm}$ as the longest pod length. Large pods favor manual harvesting, usually performed in small crop areas, predominantly by family farmers. Due to this feature, cv. BRS Tumucumaque would be recommended for cultivation in Amazonas, because it exhibited the longest pod length and, together with BRS Guariba, the second largest number of pods per plant, but the smallest number of seeds per pod, and, along with BRS Tracuateua, the lowest average grain yield, thus not justifying the choice based on pod length only (Tables 1 and 2).

For cropping systems that use semi-mechanized or mechanized harvesting, smaller pods are more suitable for handling. Because of the pods' light weight, they tend not to touch the ground, which reduces the likelihood of occurrence of losses caused by rot pods and seeds. BRS Caldeirão showed to be an ideal cultivar for semi-mechanized or mechanized harvesting, exhibiting the best performance for all parameters assessed, including a smaller pod length (Silva \& Neves, 2011; Freire Filho et al., 2011).

Regarding the number of seeds per pod (Table 2), cv. BRS Guaribaand BRS Caldeirão exhibited the highest values, 10.31 and 9.84, respectively, higher than the other species, with no significant difference between them. The average number of seeds per pod was similar to the one found by Silva and Neves (2011).

Locatelli et al. (2014) assessed the effect of use of no-tillage system and irrigation on straw mulch of Brachiaria ruzizienses with regard to the physiological characteristics of cowpea and obtained $17.6 \mathrm{~g}$ of shoot dry matter for cv. BRS Guariba, a lower value than the one found in this study. Lacerda et al. (2009) obtained a maximum value of $27 \mathrm{~g}$ of cowpea' shoot dry matter in a study conducted with $326 \mathrm{~mm}$ of water.

Shoot dry matter is considered a productivity indicator. Plants that undergo water stress close their stomata, reducing the assimilation of $\mathrm{CO}_{2}$ and photoassimilates and, consequently, the plants'shoot dry matter, growth and yields may be reduced (Oliveira, Fernandes, \& Rodrigues, 2005). Mulch provides better water retention, and the cowpea plant can respond to different stimuli from the environment, optimizing photoassimilate partitioning and increasing the accumulation of dry matter throughout the cycle, as a physiological response to ensure grain yields (Silva, Maracaja, Medeiros, F. Oliveira, \& M. Oliveira, 2009).

The interaction between the cowpea cultivars and the plant species used as dead cover was not significant. However, application of mulch favored cowpea yields compared to the control (without mulch). A similar result was found in a study with cowpea where mulching provided a greater amount of shoot dry matter and greater pod number and length (Maia Júnior et al., 2019).

In a study with soybean cultivation in succession to maize intercropped with different forage plants,there was no significant difference for the parameters assessed, which was justified by the similar process of decay and mineralization of the forage mulch (Garcia, Andreotti, Teixeira Filho, Lopes, \& Buzetti, 2014). The same may have occurred in the present study. It should be noted that in greenhouse cultivations, there is little influence from external environments, resulting in a slow decomposition process. So, because it is a short-cycle culture, mulch decay and mineralization may not have occurred in a timely manner to influence the crop yield more significantly.

According to Bastos (2017), hot temperatures during flowering may cause a significant reduction of grain yields caused by flower abortions. However, although the state of Amazonas has high temperatures, the results achieved in this study were higher than the average Brazilian yield, which is of $480 \mathrm{~kg} \mathrm{ha}^{-1}$, as recorded by CONAB (2017), thus justifying the practice of mulching. According to Mota, Libardi, Brito, Assis Júnior, and Amaro Filho (2010), mulch on the soil surface reduces evaporation and increases water storage, especially in the initial and vegetative phases of the culture.

Thus, the presence of mulch on the soil surface provided better grain yields, probably because of the greater availability of water in soil and reduced soil temperature, and also because of the incorporation of nutrients generated from the cover plants decomposition and mineralization. 


\section{Conclusion}

BRS Caldeirão is the most recommended cultivar for the state of Amazonas and other regions with similar soil and climate characteristics (high air temperature, rainfall, air humidity, and low-fertility tropical soils). Of the cultivars assessed, BRS Caldeirão exhibited a greater number of pods per plant, number of seeds per pod, amount of shoot dry mater and higher average grain yield.

There is no significant relationship between the cowpea cultivars BRS Caldeirão, BRS Tumucumaque, BRS Guariba, BRS Tracuateua and the use of mulch formed by weed species Brachiaria decumbens, Brachiaria ruziziensis and Mucuna pruriens.

Regardless of the species used in the present study, dead soil cover provides better results in the number of pods per plant, pod length, number of seeds per pod, shoot dry matter, and grain yield.

\section{Acknowledgements}

This study was financed in part by the Coordenação de Aperfeiçoamento de Pessoal de Nível Superior-Brasil (CAPES) and published with the financed support of the Programa de Apoio à Publicação de Artigos Científicos of the Fundação de Amparo à Pesquisa do Estado do Amazonas (PAPAC/FAPEAM).

\section{References}

Bastos, E. A. (2017). Cultivo de feijão-caupi (2nd ed.). Brasília, DF: Embrapa Informação Tecnológica.

Bertini, C. H. C. M., Teófilo, E. M., \& Dias, F. T. C. (2009). Divergência genética entre acessos de feijão-caupi do banco de germoplasma da UFC. Revista Ciência Agronômica, 40(1), 99-105. Retrieved from http://ccarevista.ufc.br/seer/index.php/ccarevista/article/view/410/306

Bezerra, A. A. de C., Neves, A. C., Alcântara Neto, F., \& Silva Júnior, J. V. (2014). Morfofisiologia e produção de feijão-caupi, cultivar BRS Novaera, em função da densidade de plantas. Revista Caatinga, 27(4), 135-141. Retrieved from https://periodicos.ufersa.edu.br/index.php/caatinga/article/view/3287/pdf_180

Camara, F. T., Mota, A. M. D., Nicolau, F. E. A., Pinto, A. A., \& Silva, J. M. F. (2018). Produtividade de feijão caupi crioulo em função do espaçamento entre linhas e número de plantas por cova. Revista de Agricultura Neotropical, 5(2), 19-24. https://doi.org/10.32404/rean.v5i2.2282

CONAB (Companhia Nacional de Abastecimento). (2017). Acompanhamento da safra brasileira de grãos-Safra 2017. Retrieved from http://www.conab.gov.br/OlalaCMS/uploads/arquivos/17_03_14_15_ 28_33_boletim_graosmarco_2017bx.pdf

Costa, N. R., Andreotti, M., Ulian, N. de A., Costa, B. S., Pariz, C. M., \& Teixeira Filho, M. C. M. (2015). Acúmulo de nutrientes e tempo de decomposição da palhada de espécies forrageiras em função de épocas de semeadura. Bioscience Journal, 31(3), 818-829. https://doi.org/10.14393/BJ-v31n3a2015-22434

Favarato, L. F., de Souza, J. L., \& Guarçoni, R. C. (2017). Efeitos múltiplos da cobertura morta do solo em cultivo orgânico de cenoura. Revista Brasileira de Agropecuária Sustentável, 7(2), 24-30. https://doi.org/ 10.21206/rbas.v7i2.404

Freire Filho, F. R., Ribeiro, V. Q., Rocha, M. de M., Damasceno e Silva, K. J., Nogueira, M. do S. da R., \& Rodrigues, E. V. (2011). Feijão-caupi no Brasil: produção, melhoramento genético, avanços e desafios. Teresina: Embrapa Meio-Norte. Retrieved from https://ainfo.cnptia.embrapa.br/digital/bitstream/item/844 70/1/feijao-caupi.pdf

Garcia, C. M. de P., Andreotti, M., Teixeira Filho, M. C. M., Lopes, K. S. M., \& Buzetti, S. (2014). Decomposição da palhada de forrageiras em função da adubação nitrogenada após o consórcio com milho e produtividade da soja em sucessão. Bragantia, 73(2), 143-152. https://doi.org/10.1590/brag.2014.016

Lacerda, C. F. de, Neves, A. L. R., Guimarães, F. V. A., Silva, F. L. B. da, Prisco, J. T., \& Gheyi, H. R. (2009). Eficiência de utilização de água e nutrientes em plantas de feijão-de-corda irrigadas com água salina em diferentes estádios de desenvolvimento. Engenharia Agrícola, 29(2), 221-230. https://doi.org/10.1590/ S0100-69162009000200005

Locatelli, V. da E. R., Medeiros, R. D., Smiderle, O. J., Albuquerque, J. A. A., Araújo, W. F., \& Souza, K. T. S. (2014). Componentes de produção, produtividade e eficiência da irrigação do feijão-caupi no cerrado de Roraima. Revista Brasileira Engenharia Agrícola e Ambiental, 18(6), 574-580. https://doi.org/10.1590/ S1415-43662014000600002 
Maia Júnior, S. de O., Ribeiro, J., de Andrade, J. R., dos Santos, C. M., Silva, L. K. dos S., Medeiros, A. de S., \& Reis, L. S. (2019). Solarização e cobertura morta no solo sobre a infestação de plantas daninhas no feijão-caupi (Vigna unguiculata). Revista de Ciências Agroveterinárias, 18(4). https://doi.org/10.5965/ 223811711832019466

Mota, J. C. A., Libardi, P. L., Brito, A. dos S., Assis Júnior, R. N. de, \& Amaro Filho, J. (2010). Armazenagem de água e produtividade de meloeiro irrigado por gotejamento, com a superfície do solo coberta e desnuda. Revista Brasileira de Ciência do Solo, 34, 1721-1731. https://doi.org/10.1590/S0100-06832010000500024

Novais, R. F., \& Alvarez, V. (2002). Um sistema simples de interpretação de análise de solo e recomendação de corretivos e fertilizantes. Santa Maria, RS: Anais FertBio. Retrieved from https://docplayer.com.br/ 8337114-Um-sistema-simples-de-interpretacao-de-analise-de-solo-e-recomendacao-de-corretivos-e-fertiliza ntes-1-roberto-ferreira-de-novais.html

Oliveira, A. D., Fernandes, E. J., \& Rodrigues, T. J. D. (2005). Condutância estomática como indicador de estresse hídrico em Feijão. Revista Engenharia Agrícola, 25, 86-95. https://doi.org/10.1590/S0100-6916200 5000100010

Osipitan, O. A. (2017). Weed Interference and Control in Cowpea Production: A Review. Journal of Agricultural Science, 9(12). https://doi.org/10.5539/jas.v9n12p11

Pereira, R. B., \& Pinheiro, J. B. (2012). Manejo integrado de doenças em hortaliças em cultivo orgânico. Embrapa Hortaliças. Retrieved from https:/www.embrapa.br/hortalicas/busca-de-publicacoes/-/publicacao/ 941604/manejo-integrado-de-doencas-em-hortalicas-em-cultivo-organico

Ribeiro, J. E. L. S., Hopkins, M. J. G., Vicentini, A., \& Sothers, C. (1999). Flora da Reserva Ducke: guia de identificação das plantas vasculares de uma floresta de terra-firme na Amazônia Central. Manaus: INPA.

Silva, F. E. O., Maracaja, P. B., Medeiros, J. F., Oliveira, F. de A., \& Oliveira, M. K. T. (2009). Desenvolvimento vegetativo do feijão-caupi irrigado com água salina em casa de vegetação. Revista Caatinga, 22(3), 156-159. Retrieved from https://periodicos.ufersa.edu.br/index.php/caatinga/article/view/1089/pdf

Silva, J. A. L., \& Neves, J. A. (2011). Componentes de produção e suas correlações em genótipos de feijão-caupi em cultivo de sequeiro e irrigado. Revista Ciência Agronômica, 42, 702-713. https://doi.org/10.1590/ S1806-66902011000300017

Silva, F. de A. S., \& Azevedo, C. A. V. (2016). The Assistat Software Version 7.7 and its use in the analysis of experimental data. African Journal of Agricultural Research, 11(39), 3733-3740. https://doi.org/10.5897/ AJAR2016.11522

Sousa, M. F. da C., de Castro, F. M., Damascendo, L. A., \& de Matos, H. L. (2019). Densidade de plantio do feijão-caupi na produtividade da cultura e na supressão das plantas daninhas. Revista Agrária Acadêmica, 2(4). http://doi.org/10.32406/v2n42019/102-109/agrariacad

Souza, T. M. A., Souza, T. A., Souto, L. S., \& Sá, F. V. da S., Emanoela Pereira De Paiva, E. P., \& de Mesquita, E. F. (2016). Água disponível e cobertura do solo sob o crescimento inicial do feijão-caupi cv. BRS Pujante. Revista Brasileira de Agricultura Irrigada, 10(3), 598-604. https://doi.org/ 10.7127/rbai.v10n300345

Torres, J. L. R., Cunha, M. de A., Pereira, M. G., \& Vieira, D. M. Da S. (2014). Cultivo de feijão e milho em sucessão a plantas de cobertura. Revista Caatinga, 27(4), 117-125. Retrieved from https:/www.researchgate. net/publication/269395978

\section{Copyrights}

Copyright for this article is retained by the author(s), with first publication rights granted to the journal.

This is an open-access article distributed under the terms and conditions of the Creative Commons Attribution license (http://creativecommons.org/licenses/by/4.0/). 